\title{
Nitrate Removal Efficiency with Hydrophytes of Los Reyes Aztecas Lake Water, México
}

\author{
María Guadalupe Miranda1, Antonina Galvan², Lauraceli Romero1 \\ ${ }^{1}$ Department of Hydrobiology, Universidad Autónoma Metropolitana, Mexico City, México \\ ${ }^{2}$ Department Engineering of Hydraulic Processes, Universidad Autónoma Metropolitana, Mexico City, México \\ Email: wendyfrequent@gmail.com
}

Received 26 June 2014; revised 21 July 2014; accepted 6 August 2014

Copyright (C) 2014 by authors and Scientific Research Publishing Inc.

This work is licensed under the Creative Commons Attribution International License (CC BY).

http://creativecommons.org/licenses/by/4.0/

(c) (i) Open Access

\section{Abstract}

The study was carried out to evaluate six different hydrophytes which were tested associated by twos: 1) Lemna gibba and Ceratophyllum demersum, 2) Berula erecta and Lemna gibba, 3) Polygonum punctatum and Hydrocotyle ranunculoides, and 4) Polygonum punctatum and Azolla filiculoides, for the purpose of removing nitrate from the water of Reyes Aztecas Lake, which is located southeast of Mexico City in Tláhuac District, Mexico D.F. The average of removal efficiency was obtained in relation to the different hydrophytes associations based on five sampling stations. The statistical analysis revealed that there were no significant differences among hydrophytes, all show remarkable ability to remove nitrate in water.

\section{Keywords}

Bioremediation, Nitrate, Hydrophytes

\section{Introduction}

The Reyes Aztecas lake is located southeast of Mexico City, in Tláhuac District, (D.F.). This lake constitutes a mirror of water of approximately 1.9 hectares which is formed by several primary canals of more than 50 meters wide and other secondary canals measuring between 10 to 15 meters wide. The water that feeds the lake comes from the treatment plant "Cerro de la Estrella" which is located in Iztapalapa District $\left(1.6 \mathrm{~m}^{3} / \mathrm{s}\right.$ and $\left.1.2 \mathrm{~m}^{3} / \mathrm{s}\right)$. The water arrives to the plant loaded with nitrates in addition to domestic discharges of the population residing near the riverside, generating a high concentration of nitrates [1]. 


\subsection{Nitrates}

Nitrates $\left(\mathrm{NO}_{3}\right)$ are very soluble salts, derived from nitrogen, which can be found in food and beverages. These are mainly derived from the use of nitrogen fertilizers, animal excrements, discharges of domestic and industrial waste waters, the use of food additives (canned meat and fish), of natural decomposition by microorganisms, of organic nitrogen matter like animal and plant proteins [2].

Nitrates constitute today the main source of diffuse pollution of surface and underground waters; these are water soluble substances which plants need for their development, but if these are found in large quantities they induce an excessive growth of algae and aquatic bush causing water eutrophication. When the algae and the aquatic bush die, they are decomposed by microorganisms, and thus they deplete the oxygen and make it impossible for other living beings to survive. The result is foul-smelling unusable water [3].

\subsection{Hydrophytes}

Mexico is one of the countries with the greatest biodiversity in the planet. The richness of the Mexican vegetation and flora is also represented in hydrophytes and aquatic plants. Their presence within a diversity of habitats is fundamental in the balance and development of aquatic life for being, in principle, the primary producers of the ecosystem. Their presence, coverage and structure constitute the ecological landscape of the generically called wetlands, and their health allows the conservation of the aquatic ecosystems as a whole [4].

Azolla filiculoides. Lam., belongs to, AZOLLACEAE family, it has free float lifestyle; it's abundant in Valley of Mexico; common name aquatic fern; uses, forage and green manure [4].

Berula erecta. (Huds.) Cov., belongs to APIACEAE family, it has rooted pop lifestyle; it's abundant in Valley of Mexico; common name aquatic berro; uses, medicinal, edible and forage [4].

Ceratophyllum demersum L., belongs to CERATOPHYLLACEAE family, it has free underwater lifestyle, it's low in Valley of Mexico; common name foxtail; uses, green manure and ornamental aquarium [4].

Hydrocotyle ranunculoides L., belongs to APIACEAE family, it has rooted pop lifestyle; it's abundant in Valley of Mexico; common name navel of Venus; uses, forage [4].

Lemna gibba L., belongs to LEMNACEAE family, it has free float lifestyle; it's abundant in Valley of Mexico; common name aquatic lentil; uses, forage and green manure [4].

Polygonum punctatum Ell., belongs to POLYGONACEAE family, it has rooted pop lifestyle; it's abundant in Valley of Mexico; common name aquatic chili; uses, forage [4].

\subsection{Background}

The rise of biological research related with water treatments using hydrophytes has opened a vast field filled with hope due to its low cost and simple infrastructure [5].

Furthermore, their prominent ability of nutrient assimilation and the creation of favorable conditions for the decomposition of organic matter are widely known [6]-[9].

These characteristics promote hydrophytes in the use of wastewater treatment systems [10].

Lemna gibba, Myriophyllum and Eichhornia crassipes have been used separately for the removal of nitrates from waste water with the following results: an efficiency rate of $32 \%, 82 \%$ and $0 \%$ respectively [11].

In another study, three hydrophytes were used for the removal of nitrates from domestic waste waters obtaining the following results: Eichhornia crassipes, had an efficiency rate of $15.38 \%$, Lemna gibba 31.25\% and Azolla filiculoides 22.22\% [12].

In another research is working with three aquatic plants: Eichhornia crassipes, Pistia stratiotes and Lemna gibba, for the removal of nitrates from waste water supplied by a waste digester fed by excrements from bovine cattle, obtaining the following results: an efficiency rate of 70\%, 73\% and 99\% respectively [13].

Campanella et al. 2005 used Eichhornia crassipes for the removal of nitrates originated from a waste pipe located in a metallurgical industrial plant Bahco Argentina S.A. in the city of Santo Tomé, obtaining a removal efficiency rate of $50 \%$ [14].

Núñez et al. 2007, used Lemna sp and Typha dominguensis for the removal of nitrates from waste waters obtaining the following results: an efficiency rate of $18 \%$ and $36 \%$ respectively [15].

The objective of this study is to prove the efficiency to remove nitrates from water with six different hydrophytes associated by twos, at five different stations of the Los Reyes Aztecas lake in Tláhuac District. 


\section{Materials and Methods}

\subsection{Area of Study}

Reyes Aztecas Lake is located in the San Pedro neighborhood, in Tláhuac District, which in turn, is located southeast of Mexico City, within the Mexico Basin, bordering to the north and northeast with the Iztapalapa District, to the south with Milpa Alta, to the east and southeast with the Valle de Chalco municipality in the State of Mexico, and finally it is located west of Xochimilco District [16]. It is located between the coordinates $19^{\circ} 19^{\prime} 2.3^{\prime \prime}$ North and $99^{\circ} 00^{\prime} 55.5^{\prime \prime}$ West, the approximate altitude is 2240 m.a.s.l., the climate is temperate with humidity variations (See Figure 1) [17].

\subsection{Water and Hydrophytes Sampling}

A total of five sampling sites were established; station 1 at the pier, station 2 secondary canal (near houses, Cisneros street), station 3 bovine cattle breeding area, station 4 near a spring and station 5 in the water spillway from the Cerro de la Estrella treatment plant; these are the places where water samples were taken during the months of June 2011, September 2012, October 2012 and November 2012, the samples were carried to the laboratory in plastic bottles inside an ice cooler.

The samples of hydrophytes: Azolla filiculoides, Berula erecta, Ceratophyllum demersum, Hydrocotyle ranunculoides, Lemna gibba and Polygonum punctatum, were collected manually in the secondary canals of the Reyes Aztecas Lake, these were placed inside a plastic ice cooler in order to be carried to the laboratory.

The bioassay was carried out in a controlled light laboratory with a light/darkness 12/12 photoperiod on eight plastic trays. For each station, four associations were used which were made in triplicate, a witness without plants was used for every station and every association. The trays had the following size: $30.5 \mathrm{~cm}$ long, $15.5 \mathrm{~cm}$ wide and $10 \mathrm{~cm}$ high, to which $2000 \mathrm{ml}$ of water from the lake were added. The four associations that were used were: Lemna gibba and Ceratophyllum dermesum, Berula erecta and Lemna gibba, Polygonum punctatum and Hydrocotyle ranunculoides, Polygonum punctatum and Azolla filiculoides.

At the beginning of the bioassay the nitrogen was measured in the form of nitrates by the method of Cataldo, [18] these were kept for a period of fifteen days, after which this determination was repeated. The efficiency was obtained in relation percentages of the initial values minus the final values divided by the initial values times 100.

\subsection{Statistical Analysis}

The bioassay was made with 3 replications for each treatment and the data were analyzed with a coefficient of variation (C.V.) and analysis of variance method (ANOVA) from Number Cruncher Statistical System (NCSS version 2001) at $5 \%$ significant rate.

\section{Results and Discussion}

Table 1 shows average nitrates of five sampling sites, asosociations hydrophytes, removal efficiency and coefficient of variation with respect each sampling site, where the number 3 display the highest homogeneity and the highest heterogeneity is displayed by number 5 .

According to the ANOVA analysis, the average of removal efficiency in relation to the different hydrophyte associations do not display significant differences $\mathrm{F}_{2.16}=0.21$; $(\mathrm{P}>0.05)$. See Figure 2 .

On the other hand, the average of removal efficiency with relation to the five stations do not display significant differences according to $F_{2,16}=0.21$; $(P>0.05)$, although it was observed that station 1 has only a $44.25 \%$ of removal efficiency and all the other stations more than $70 \%$. See Figure 3.

Table 2 shows the coefficient of variation with respect to the associations, where the association Lemna and Ceratophyllum display the highest homogeneity and the highest heterogeneity is displayed by Polygonum and Hydrocotyle.

Comparing previous works regarding Lemna we obtained an average of removal efficiency of $71.8 \%$ associated with Ceratophyllum and $77 \%$ associated with Berula, this value is higher than the one in the [11] reports, who obtained 32\%; [12] obtained 31.25\% and [15] 18\%. But the value is lower to that published by [13] who obtained 99\%. In this work Azolla presented a removal efficiency of $67.2 \%$ associated to Polygonum, a much 


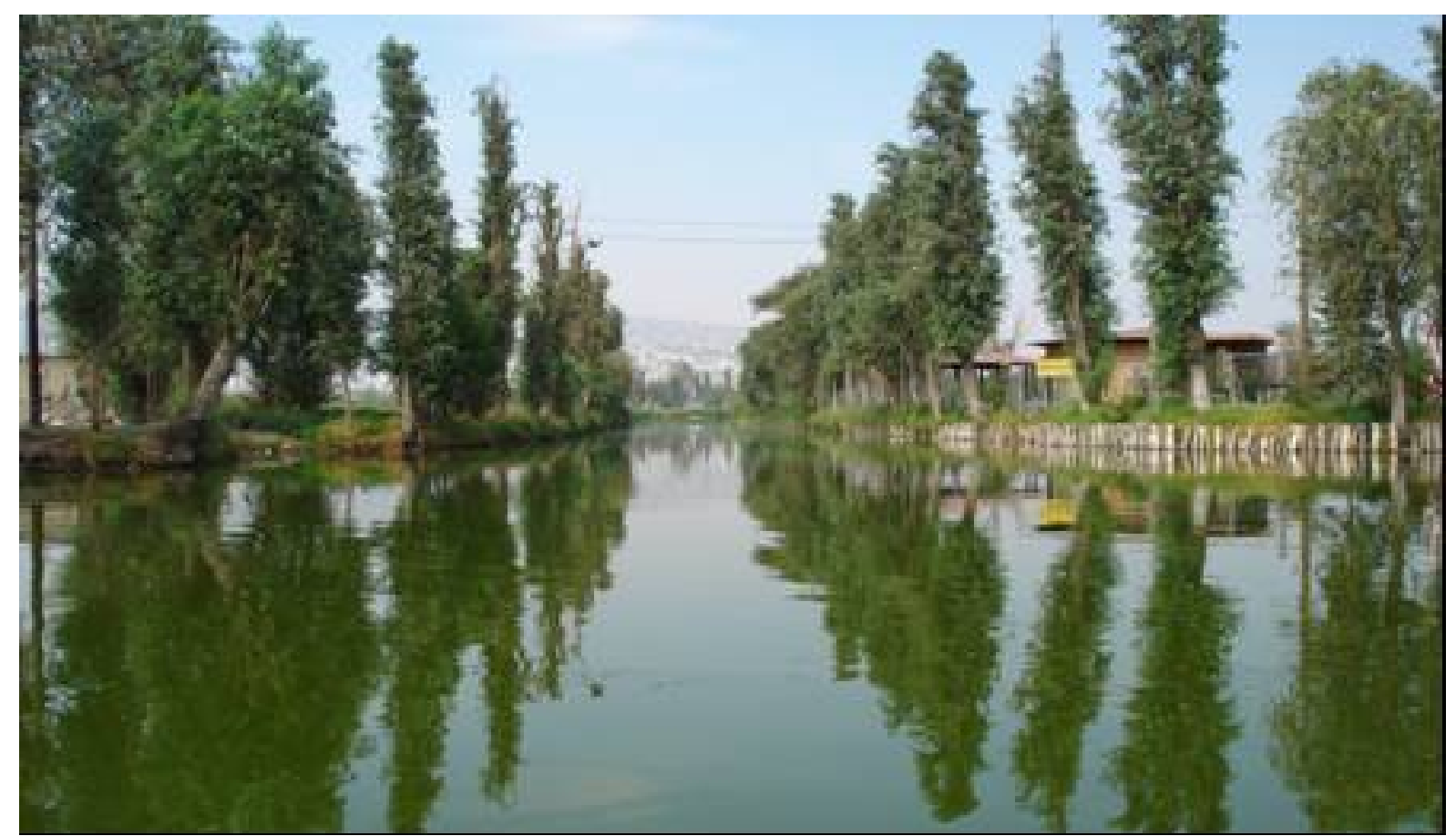

Figure 1. Localization of Reyes Aztecas Lake in Tláhuac District, Distrito Federal, México.

Table 1. $\mathrm{NO}_{3}$ concentration by initial and final sampling site; nitrate removal efficiency and coefficient of variation (C.V.).

\begin{tabular}{|c|c|c|c|c|c|}
\hline $\begin{array}{l}\text { SAMPLING } \\
\text { SITES }\end{array}$ & $\begin{array}{l}\text { ASSOCIATIONS } \\
\text { (Hydrophytes) }\end{array}$ & $\begin{array}{c}\text { INITIAL } \\
\text { CONCENTRATIÓN } \\
\mathrm{NO}_{3}(\mathrm{mg} / \mathrm{L})\end{array}$ & $\begin{array}{c}\text { FINAL } \\
\text { CONCENTRACION } \\
\mathrm{NO}_{3}(\mathrm{mg} / \mathrm{L})\end{array}$ & $\begin{array}{l}\text { REMOVAL } \\
\text { EFFICIENCY } \\
(\%)\end{array}$ & C.V. \% \\
\hline \multirow{4}{*}{1} & Lemna_Ceratophyllum & 2.2 & 1.3 & 38 & \multirow{4}{*}{38.3} \\
\hline & Berula-Lemna & 2.2 & 1.8 & 17 & \\
\hline & Polygonum-Hydrocotyle & 2.2 & 1.0 & 54 & \\
\hline & Polygonum-Azolla & 2.2 & 0.7 & 68 & \\
\hline \multirow{4}{*}{2} & Lemna-Ceratophyllum & 9.4 & 1.2 & 87 & \multirow{4}{*}{86.2} \\
\hline & Berula-Lemna & 9.4 & 0.2 & 98 & \\
\hline & Polygonum-Hydrocotyle & 9.4 & 3.5 & 63 & \\
\hline & Polygonum-Azolla & 9.4 & 1.6 & 83 & \\
\hline \multirow{4}{*}{3} & Lemna-Ceratophyllum & 14.5 & 1.4 & 90 & \multirow{4}{*}{34.5} \\
\hline & Berula-Lemna & 14.5 & 0.9 & 94 & \\
\hline & Polygonum-Hydrocotyle & 14.5 & 1.4 & 90 & \\
\hline & Polygonum-Azolla & 14.5 & 0.6 & 96 & \\
\hline \multirow{4}{*}{4} & Lemna_Ceratophyllum & 5.5 & 2.6 & 53 & \multirow{4}{*}{62.0} \\
\hline & Berula-Lemna & 5.5 & 1.2 & 78 & \\
\hline & Polygonum_-Hydrocotyle & 5.5 & 1.1 & 80 & \\
\hline & Polygonum-Azolla & 5.5 & 0.6 & 89 & \\
\hline \multirow{4}{*}{5} & Lemna-Ceratophyllum & 24.5 & 2.1 & 91 & \multirow{4}{*}{103.5} \\
\hline & Berula-Lemna & 24.5 & 0.4 & 98 & \\
\hline & Polygonum-Hydrocotyle & 24.5 & 8.5 & 65 & \\
\hline & Polygonum-Azolla & 24.5 & 2.6 & 89 & \\
\hline
\end{tabular}




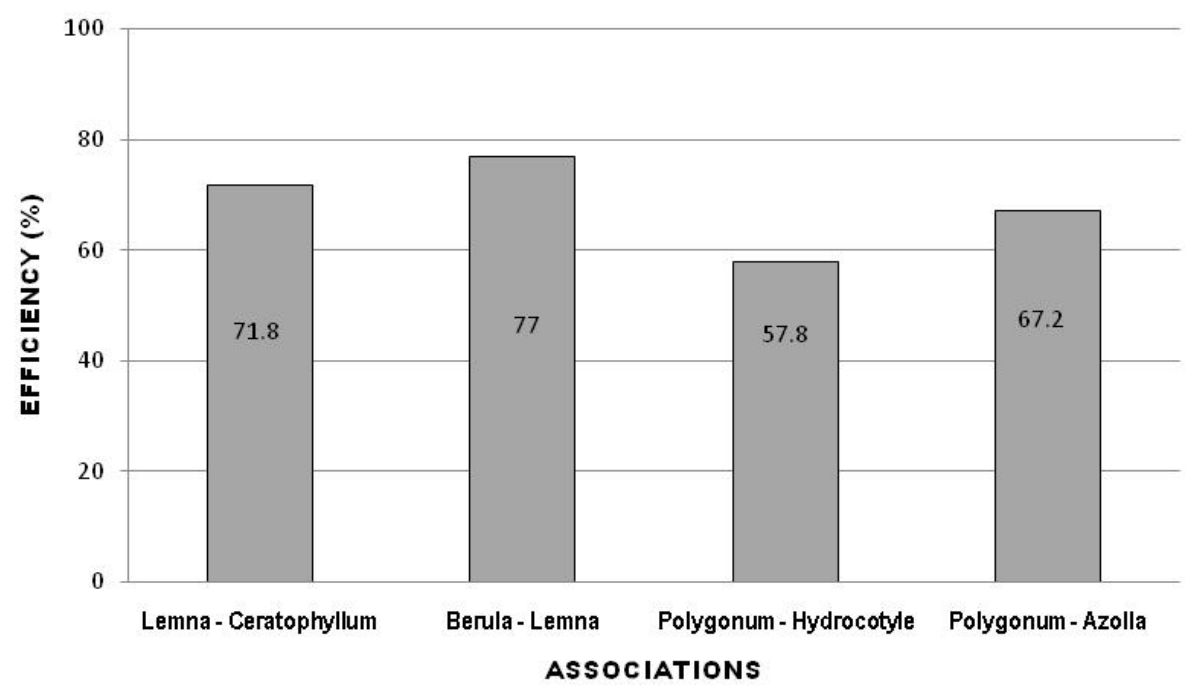

Figure 2. Removal efficiency (\%) vs hydrophytes associations.

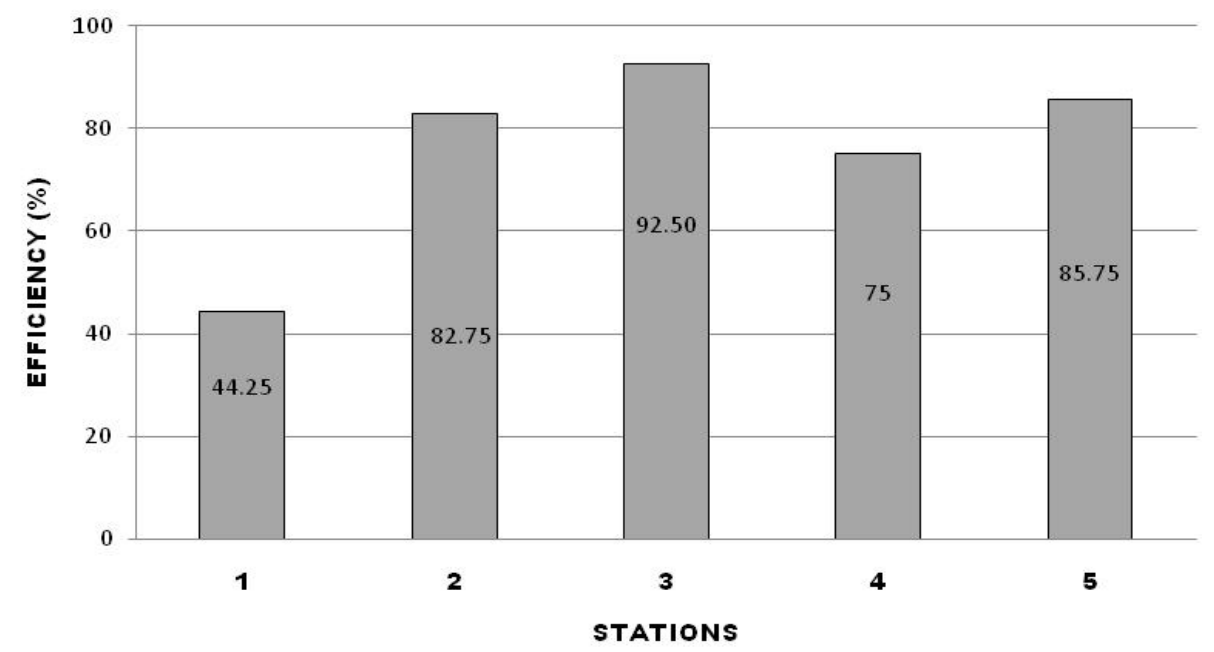

Figure 3. Removal eficiency (\%) vs sampling sites.

Table 2. Coefficient of variation with respect different associations.

\section{HYDROPHYTES ASSOCIATIONS}

Polygonum-Hydrocotyle

Polygonum-Azolla

Berula-Lemna

Lemna-Ceratophyllum
C.V. \%

102.7

71.3

71.1

34.8

higher value than the $22.22 \%$ reported [12].

\section{Conclusion}

In this way the study leads us to conclude that the six different species hydrophytes associated by twos evaluated here all show same remarkable ability to remove nitrate in water, at five different stations of Los Reyes Aztecas Lake, Tláhuac, D.F., supporting highly the use of hydrophytes in domestic waste water treatment since it is cheap and environmental friendly. 


\section{References}

[1] Ortiz, D. and Ortega, M. (2007) Origin and Evolution of a New Lake in the Plain of Chalco: Hazard Implications Subsidence and Flooding of Urban Areas in Valle de Chalco (Mexico State) and Tláhuac (Federal District). Geographical Research Bulletin of the Institute of Geography, 64, 26-42.

[2] García, M., García, M. and Cañas, R. (1994) Nitrates, Nitrites and N-Nitroso Compounds. Editor Pan American Center for Human Ecology and Health, Division of Health and Environment, México, 21-25.

[3] Ortiz, J.L. (1991) Quantitative Relationships between Nutrient Input and Eutrophication. Memory of the Days Eutrophication and Biological Indicators. CEDEX, Madrid, 155-182.

[4] Lot, A., Novelo, A. and Esperanza, E. (2004) Iconography and Studies of Aquatic Plants in Mexico City and Surroundings. Biology Institute, UNAM, México D.F., 9-16.

[5] Florez, A. (1994) Removal of Pollutants from Wastewater with Aquatic Macrophytes. Dugandia, 5, 25-32.

[6] Gersberg, R.M., Elkins, B.V., Lyon, S.R. and Goldman, C. (1986) Role of Aquatic Plants in Wastewater Treatment by Artificial Wetlands. Water Research, 20, 363-368. http://dx.doi.org/10.1016/0043-1354(86)90085-0

[7] Brix, H. and Schierup, H. (1989) The Use of Aquatic Macrophytes in Water-Pollution Control. Ambio, 18, $100-107$.

[8] Ellis, J., Shutes, R., Revitt, D. and Zhang, T. (1994) Use of Macrophytes for Pollution Treatment in Urban Wetlands. Resources, Conservation and Recycling, 11, 1-12. http://dx.doi.org/10.1016/0921-3449(94)90074-4

[9] Peterson, S. and Teal, J. (1996) The Role of Plants in Ecologically Engineered Wastewater Treatment Systems. Ecological Engineering, 6, 137-148. http://dx.doi.org/10.1016/0925-8574(95)00055-0

[10] Kara, Y. (2004) Bioaccumulation of Copper from Contaminated Wastewater by Using Lemna minor. Bulletin of Environmental Contamination and Toxicology, 72, 467-471. http://dx.doi.org/10.1007/s00128-004-0269-4

[11] Romero, L., Ramírez, F., Álvarez, C. and Miranda, M.G. (2011) Using Hydrophytes and an Anaerobic System to Treat Wastewater Trail. Polibotánica, 31, 157-167.

[12] León, M. and Lucero, A. (2009) Study Eichhornia crassipes, Lemna gibba and Azolla filiculoides in the Biological Treatment of Domestic Sewage in a Community and Single-Family System Catacachi Canton. Professional Thesis, Technical University of the North, Faculty of Agricultural Engineering and Environmental Science, Ibarra, 141-142.

[13] Pedraza, G. (1994) Recycling Animal Effluent with Three Species of Aquatic Plants. Livestock Research for Rural Development, 6, 1-7.

[14] Campanella, M.V., Hadad, H., Maine, M.A. and Markariani, R. (2005) Effects of Sewage Effluent Phosphorus on the Internal and External Morphology of Eichhornia crassipes (Mart. Solms) in a Wetland. Limnetica, 24, 263-272.

[15] Núñez, M., Cárdenas, F., Cárdenas de Flores, C., Ramírez, H., Rincón S. and Morales, E. (2007) Nitrogen Removal in Wastewater through Plant Typha dominguensis and Lemna sp. AIDIS Engineering and Environmental Sciences and Research, Development and Practice, 1, 198-204.

[16] Martínez, B. (2008) Tlahuac Freedom and Wisdom 12 Years Wreath Polar. Electronic Journal of American Culture in Canada. http://gpolar.com/page/read/534

[17] Ramos Bello, R., Cajuste, J.L., Flores-Roman, D. and García Calderón, E.N. (2001) Heavy Metals, Salts and Sodium in Chinampa Soils, Mexico. Agrociencia, 35, 385-394.

[18] Cataldo, D., Maroon, M., Schrader, L. and Young, V. (1975) Rapid Colorimetric Determination of Nitrate in Plant Tissue by Nitration of Salicylic Acid. Communications in Soil Science and Plant Analysis, 6, 71-80. http://dx.doi.org/10.1080/00103627509366547 
Scientific Research Publishing (SCIRP) is one of the largest Open Access journal publishers. It is currently publishing more than 200 open access, online, peer-reviewed journals covering a wide range of academic disciplines. SCIRP serves the worldwide academic communities and contributes to the progress and application of science with its publication.

Other selected journals from SCIRP are listed as below. Submit your manuscript to us via either submit@scirp.org or Online Submission Portal.
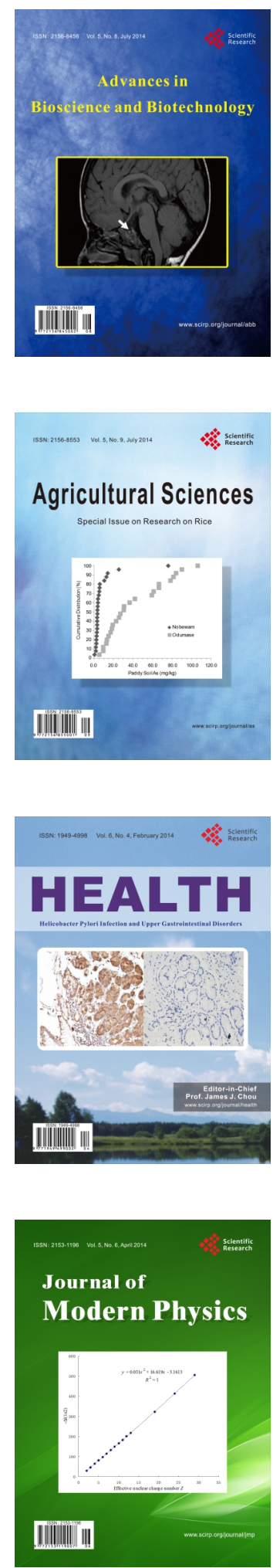
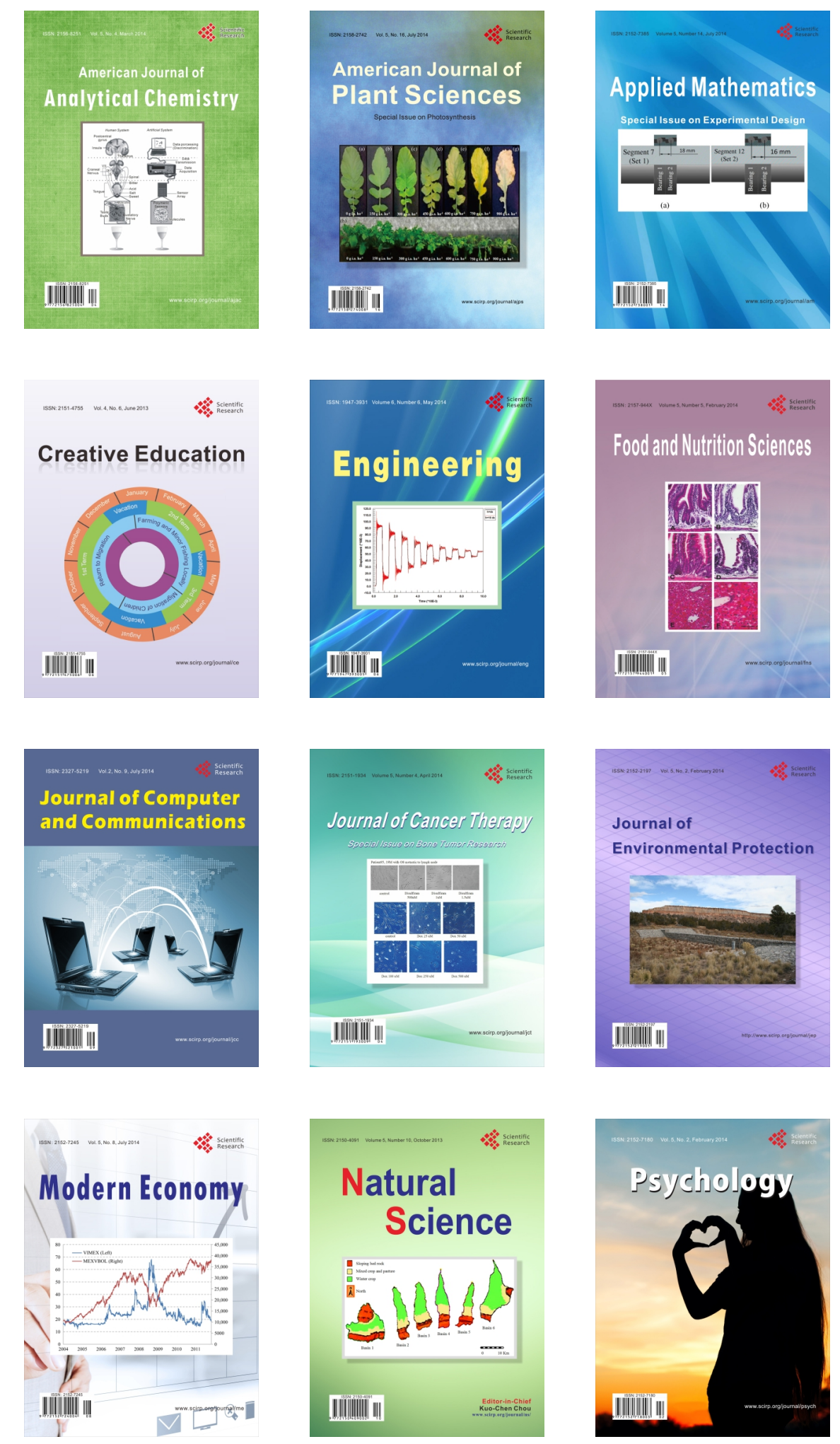